\title{
Os pares cranianos e a era da comunicação
}

Recentemente tivemos notícia do último levantamento mundial de acesso e uso de sistemas de informação interligados pela rede mundial de computadores e provedores (web) via Internet e Intranet. Só em nosso país são quase 40 milhões de pessoas que se utilizam deste meio para trânsito de informação, sendo considerado o terceiro país em acesso da Internet do mundo.

O que parecia impossível parece que vai tomando forma de maneira irrevogável. Em pouco tempo, cada cidadão com acesso aos direitos civis ocidentais mais corriqueiros terá um ponto de comunicação com qualquer outro indivíduo, nas mesmas condições, em qualquer localidade do planeta.

Esta é uma situação filosoficamente instigante. Vejamos, compartilhamos do mesmo meio ambiente e dos mesmos meios de sobrevivência, respeitamos regras éticas, morais e culturais cada vez mais próximas e estamos praticamente interligados por uma rede de informações semelhante a uma rede neural. Indo além, percebemos que uma vez recebida uma informação do meio exterior, uma empresa, família ou indivíduo pode conectar e transmiti-la a outro sítio da empresa, da casa ou de seu escritório pela intranet. A aldeia global está cada vez mais próxima de um sistema biológico único e integral.

O que mantém e representa esta integridade é nossa capacidade de recolher as informações do ambiente e da rede global, veiculada pelo sistema de receptores instalados nos aparelhos sensoriais. Recapitulando, contamos o sistema visual, com os seus $2^{\circ}, 3^{\circ}, 4^{\circ}$ e $6^{\circ}$ pares cranianos, 0 sistema olfatório com o Io. par craniano, o sistema auditvo e vestibular com o $8^{\circ}$ par, o sistema gustativo com o Vo. par e finalmente o "sistema sensorial" do ambiente interno, com seus sinalizadores especiais, receptores característicos e mensageiros intracelulares peculiares.

Rapidamente, podemos observar que grande parte de nossa relação com o ambiente externo e, portanto, de nossa saúde social, está contida em matéria de interesse do otorrinolaringologista. Resta saber se o especialista tem se comprometido com a ampliação do conhecimento do assunto e quanto tem contribuído para a melhoria da condição comunicativa do ser humano.

Levando a discussão para o tema comunicação, tomamos duas vertentes bastante interessantes, a primeira diz respeito à nossa capacidade de comunicação com o exterior e isto significa, tato, temperatura, visão, audição, olfato, paladar, movimento muscular, voz e fala. Estes sistemas devem se manter conectados para compor o que podemos chamar de nossa "representação interior" do ambiente externo. Para que isto aconteça, devemos ter aprendi- do e treinado uma lógica de compartilhamento de informações que tenha um mínimo de coerência com o que realmente existe além do horizonte corporal. É aí que surge a segunda vertente, obviamente não dissociável da primeira, que é o sistema "sensorial" interno. A interligação e troca de informações entre cada sistema é feita de maneira individual, célula a célula, e pode ser feita a partir de sinalizações de diversos tipos. Há os sinais endócrinos que, com moléculas chamadas de hormônios, levam ordens e informações a células-alvo em sítios distantes do seu local de síntese pelos órgãos endócrinos. Há a sinalização parácrina, onde as moléculas sinalizadoras liberadas por uma célula afetam apenas as células-alvo em íntima proximidade com ela. Também há a sinalização autócrina, onde as células respondem a substâncias liberadas por elas mesmas.

Cada um dos métodos de sinalização lança mão de moléculas que se ligam a algum receptor de superfície, ou de citosol ou mesmo de núcleo da célula em que vai atuar. Os receptores podem ser de diversos tipos e hoje sabemos que pouco sabemos sobre a sua magnitude no controle funcional humano. Além disso, no interior das células temos os chamados segundo mensageiros como o AMPc, GMPc, IP3 , etc. que modulam e transferem as informações para as diversas organelas intracelulares. Portanto, o sistema de comunicação interno pode ser tão ou mais complexo que o sistema externo. Mas de todo modo, tem uma similaridade muito grande.

É através da integridade e boa atuação da comunicação interna que podemos compor respostas adequadas aos estímulos e situações externas que garantam a nossa sobrevivência.

Repassando o termo médico cada vez mais utilizado e respeitado de atuação e compreensão holística do indivíduo, que considera o corpo humano como um todo e, indecomponível associando seu significado ao de saúde total, em que se considera que não é suficiente ter funções vitais ativas sem que se atinja boa qualidade de vida, concluímos que o alcance das necessidades de inter-relação de um indivíduo com outro, como células de um mesmo organismo, é fundamental para quem tem em sua atividade principal o auxílio ao equilíbrio biológico, como é o caso do médico.

No caso da Otorrinolaringologia, estamos acordando para as cada vez maiores responsabilidades a que nos associamos no afã de oferecer melhores condições de sobrevivência ao ser humano. O declínio de doenças crônicas nasosinusais e otológicas e o aumento do conhecimento das habilidades funcionais como voz, audição sono etc. vai levando o especialista a ter atuação em matérias que 
outrora não tinha contato. É a primeira vertente sendo mais e mais reconhecida e dominada pelo otorrinolaringologista. Entretanto, se observarmos o número de publicações relativas ao ambiente interno e ao sistema de comunicação celular nos tópicos de interesse da audição, fala, olfato e paladar, notamos que temos falhado em apresentar dúvidas e, ainda pior, soluções para os possíveis engarrafamentos ocorridos nos sistemas de sinalização e troca de informações intracelulares. Isto, ao final, significa pouco conhecimento de células-alvo, de sinalizadores, receptores, mensageiros e respostas celulares para cada um dos setores compreendidos pelos pares cranianos de nossa esfera de responsabilidade. Isto acaba por reduzir nossa capacidade de oferecer necessidades de desenvolvimento de drogas ativas na região, limita o reconhecimento de genes ativos e impossibilita o uso de estratégias que orientem os hábitos alimentares para resolução de afecções otorrinolaringológicas.
Hoje, a Biologia molecular já nos forneceu dados quanto a diversas atividades e seus atores como alguns cátions, proteínas e hormônios nas células da orelha interna, laringe, nariz e boca. Mas há muito por fazer e a tarefa está muito atrasada se comparada com outras disciplinas da Medicina.

Tenho a impressão que a Medicina será outra quando as dúvidas relacionadas aos sistemas de controle funcional celular forem melhores conhecidos. Talvez seja uma excelente oportunidade para a Otorrinolaringologia saltar definitivamente dos porões para a cobertura do edifício onde os estudiosos da saúde estão instalados. Cabe a cada um de nós meditar sobre isto. Cabe à Revista Brasileira de Otorrinolaringologia estimular nossa curiosidade. Cabe ao otorrinolaringologista cumprir sua função de médico com uma visão holística do ser humano.

Henrique Olival Costa 